\title{
Protecting the Village Credit Institution: Should Traditional Communities Adopt Modern Financial Management Practices?
}

\author{
Luh Putu Yeyen Karista Putri* \\ Eric Gordon Withnall** \\ Jude Lawyers, Darwin, Australia
}

PT. Indo-Ned Consultancy, Legal Consultancy, Bali, Indonesia.

\begin{abstract}
A Lembaga Perkreditan Desa (Village Credit Institution or LPD) is a type of financial institution that is associated with a Balinese customary village. LPDs face competing pressures to both maintain their traditional character and align themselves with national standards for financial management. This article establishes the hybrid legal character of LPDs (under Balinese customary law and Indonesian national law) in order to analyse their evident shortcomings, being the vulnerability of some monitoring and protection systems to misappropriation. We rely on normative legal research methods, including statutory analysis and analysis of case studies. We examine the LPD Regulations and Balinese customary law, supplemented by interviews on issues of relevance. We conclude that the recognition of LPDs under the law, given the fundamental basis of the LPD in the customary village, ought to be given primacy to their status under Balinese customary law. However, the monitoring and protection systems of LPDs must be improved and uniform standards must be enforced - otherwise, their customers will simply use other financial institutions. We also conclude that it is possible to improve management practices while respecting the autonomy of customary villages. Therefore, we assert that properly implemented measures will make a direct intervention from government unnecessary.
\end{abstract}

Keywords: Village Credit Institution; Community-Based Financial Institution; Customary Community in Bali.

How to Cite (chicago-16th): Karista Putri, Luh Putu Yeyen, and Eric Gordon Withnall. "Protecting the "Village Credit Institution": Should Traditional Communities Adopt Modern Financial Management Practices?" Udayana Journal of Law and Culture 2, no. 2 (2018): 115-139. https:/ / doi.org/110.24843/UJLC.2018.v02.i02.p01.

DOI: https://doi.org/10.24843/UJLC.2018.v02.i02.p01

* E-mail/Corresponding Author: putuyeyen22@gmail.com

** E-mail: eric.withnall@gmail.com 


\section{Introduction}

\subsection{Background}

The Lembaga Perkreditan Desa ('village credit institution', or 'LPD') is a communitybased financial institution and charitable entity indigenous to traditional communities in Bali province, Indonesia. Despite its small size and limited asset holdings, some LPDs have successfully become an effective solution to the economic crises faced by individuals and local communities in Bali. ${ }^{1}$

The primary objective of LPDs, as they exist in Bali, is to support the economic and social development of traditional communities in accordance with the traditional principles of Tri Hita Karana. ${ }^{2}$ Bali consists of at least 1,500 traditional communities who live in a certain territory, a customary village (known as desa pakraman), ${ }^{3}$ and 1,433 of them have their own LPD. ${ }^{4}$ Given the role of the customary village in both the governance and regulation of LPDs, differences between communities result in non-uniformity of the sector - in the same way that each LPD reflects its associated community, their standards fluctuate based on the level to which governance standards are applied and asserted by community leaders.

Despite the discrepancy in their regulations, all LPDs carry out similar activities, such as: giving personal loans; collecting public funds in the form of savings; maintenance of common amenities; direct funding of cultural activities; and various welfare initiatives, as deemed necessary by the customary village. As the financial arm of the customary law village (which has a legal personality of its own), LPDs fulfil a number of functions that are traditionally held (under Western legal systems) to be within the remit of the State: as such, they form an integral part of de facto traditional governing authority that exists in Bali's pluralistic legal system.

LPDs are unusual, if not unique, in the degree to which they straddle two different systems of law. On one hand, they are an institution that is inseparable from the customary village, as the entity is recognised under inseparable from the customary village, as the entity is recognised under Balinese customary law. Thus, it reflects

1 Carol Warren, "Adat in Balinese Discourse and Practice," in The Revival of Tradition in Indonesian Politics: The Deployment of Adat from Colonialism to Indigenism, ed. Jamie S. Davidson and David Henley (Oxford: Routledge, 2007), 179.

2 See further in Subsection 2.1.2.

3 Hanna Christine Ndun, Sarah Suttor, and I Gusti Agung Ayu Dike Widhiyaastuti, "Does Customary Law Discriminate Balinese Women's Inheritance Rights?” Udayana Journal of Law and Culture 2, no. 1 (2018): 98, https://doi.org/10.24843/UJLC.2017.v02.i01.p05.

4 Kabarnusa.com, "Kekayaan LPD di Bali capai 15,5 Triliun", April 29, 2017, https:/ / www.kabarnusa.com/2017/04/kekayaan-lpd-di-bali-capai-rp155-triliun.html. 
economic activities that are organized by a cultural-based institution. ${ }^{5}$ On the other hand, the national law of Indonesia classifies them as a form of legal entity - and one distinct from Micro-Finance Institutions (MFIs). Despite sharing traits with MFIs, they are exempted from many of the regulatory requirements imposed on MFIs. ${ }^{6}$ The apparent policy assessment by the authorities is that the regulatory stance on LPDs is justified by their demonstrable role in increasing the wealth of customary village - not only in the purely economic sense but in socio-cultural aspects as well as local wisdom. ${ }^{7}$ In addition, the existence of LPDs are regulated by local regulations enacted by provincial and regency or municipality governments in Bali.

The continued role of the LPD in Balinese life is endangered. Some State institutions have frequently questioned the security provided to customers who bank with LPDs, taking into account that LPDs do not participate in the Indonesia Deposit Insurance Corporation. ${ }^{8}$ The response has largely been one encouraging consumer prudence: for example, the Central Bank of Indonesia has urged the establishment of an independent institution that is assigned to periodically monitor and audit the operations of all LPDs in Bali. ${ }^{9}$ The Indonesia Financial Services Authority occasionally issues statements reminding customers of the risks of LPDs and suggesting that critical failure is possible: i.e. customers not being able to withdraw money. ${ }^{10}$ LPDs have also been classed alongside MFIs by a Joint Decree issued by the Minister of Finance, Minister for Domestic Affairs, Minister of Co-operative and Small and Middle size-Enterprises, and Governor of the Central Bank of Indonesia. ${ }^{11}$

Representatives of Bali's LPDs have almost unanimously rejected the controlling approach of the national government. Through the Assembly of Balinese Customary Villages (Majelis Desa Pakraman), a conference representing 1.423 communities, it was agreed to establish a so-called Council of LPD (Dewan LPD) that may have

5 A legal study that focuses on the link between the aspects of culture and economics in Bali suggested that culture should be regarded as economic resources, in which customary villages in Bali should play a role. According to this concept, LPD as an institution belongs to the customary village reflects both economics function and cultural symbolic. See Salain, Made Suksma Prijandhini Devi, "Perlindungan Hukum Terhadap Kebudayaan Bali Sebagai Sumber Daya Ekonomi Pariwisata,"Kertha Patrika 39, no. 1 (2017): 4, 13.

doi: https://doi.org/10.24843/KP.2017.v39.i01.p01

6 See further in Section 2.1.1.

7 Kontan, "BI Bali desak pembentukan pengawasan LPD”, October 18, 2016, http: / / regional.kontan.co.id/news / bi-bali-desak-pembentukan-pengawasan-lpd.

8 Lembaga Penjamin Simpanan, "Establishment, Status, and Designated Positions of IDIC," Lembaga Penjamin Simpanan, accessed May 1, 2018, http://www.lps.go.id/en/web/guest/bentuk-status.

9 Kontan, Op. Cit.

10 Indonesia Satu, “OJK Ingatkan LPD Bali yang Gagal Bayar Uang Nasabah”.Co, August 24, 2016, http://indonesiasatu.co/detail/ojk-ingatkan-lpd-bali-yang-gagal-bayar-uang-nasabah.

11 Joint Decree by Minister of Finance, Minister for Domestic Affairs, Minister of Co-operative and Small and Middle size- Enterprises, and Governor of Central Bank of Indonesia No: 351.1/KMK.010/2009; No: 900-639A Tahun 2009; No: 01/SKB/M.KUKM/IX/2009; No: 11/43A/KEP.GBI/2009 concerning Strategy to Develop Micro Finance Institution, Para 1. 
a function in setting policy and standards that resembles that of the Central Bank of Indonesia. ${ }^{12}$

In the meantime, it cannot be denied that LPDs (in many cases) are currently facing challenges regarding customer satisfaction, as is reflected by customer surveys, complaints, and behaviour that indicates loyalty to their LPD. ${ }^{13}$ The high rate of economic growth in Bali has affected the success of LPDs, with a number of them now holding more assets and capital than local MFIs. In response to this success, the Provincial Government of Bali has enacted particular regulations to control the operations of LPDs: particularly by regulating their management practices, monitoring requirements, and the legal rights of LPD customers.

However, the strong influence of customary law in the management and operation of LPDs means that a number of functions have been duplicated (for example the monitoring and reporting requirements). As a result, the increasing influence of State law in the control of LPDs is challenging their status as traditional institutions that act as an extension, and the financial embodiment, of the community - a role they have held until now.

\subsection{Purpose of Research}

This article offers both legal and cultural perspectives on the status of LPD under the National Law of Indonesia and the Customary Law of Bali. Specifically, from an economic perspective to law, it will critically analyse institutional responses to customer protection issues, and it will particularly examine the monitoring and protection mechanisms used by these institutions. Regarding the monitoring mechanism, this paper will also address shortfalls in agencies that have the statutory responsibility to supervise the operation of LPDs, including the ways they address consumer risk.

\subsection{Method and Structure}

As part of our legal research, this study incorporates published Indonesian laws that can be obtained from national databases. These include Act No. 1 Year 2013 regarding Micro-Finance Institutions and Local Regulation of Bali Province No. 3 Year 2017 concerning LPD ('LPD Regulations'), and Governor's Regulation of Bali No. 44 Year 2017 ('the Implementing Rules'). This article also looks at how customary law existed in customary villages in Bali known as Awig-awig or Perarem.

12 AA Seri Kusniarti, "Dewan LPD Seperti Bank Indonesia”, Tribun Bali, October 23, 2015, http:/ / bali.tribunnews.com/2015/10/23/dewan-lpd-seperti-bank-Indonesia.

13 Gede Putu Agus Jana Susila, "Pengukuran Kinerja Lembaga Perkreditan Desa (LPD) Kecamatan Susut Dengan Analisis Balanced Scorecard," Jurnal Ilmu Sosial dan Humaniora 5, no.2 (October 2016): 813. https://doi.org/10.23887/jish-undiksha.v5i2.8564. 
A case study has been made, focussing on the LPD associated with Desa Adat Pecatu. This institution is recognised as one of the leading LPDs in Bali based on the size of their asset holdings and their successful management of those assets. A few years ago, LPD Pecatu was rewarded as being the most outstanding LPD in the region of Badung, Bali, in the category of institutions holding assets valued at over Indonesian Rupiah (IDR) 1 Billion. ${ }^{14}$ Their success in the role suggests that it is important to examine the rules and policies that are implemented by similar LPDs, particularly regarding their monitoring and protection systems so that other LPDs in Bali can learn from it. In addition, our interviews with Chief and Senior staff of the institution have allowed us to collect data related to the implementation of these monitoring and protection systems.

Section 2.1. of this article will provide analysis on the legal status of LPD under Balinese Customary Law and national law. Section 2.2 will deal with the issue of the monitoring system of LPDs, while section 2.3 will discuss the protection systems implemented by LPDs.

\subsection{Literature Review}

Individual LPDs may not appear significant from a national perspective, given their relative size and asset holdings. However, the concept of a community-based financial institution can provide a boost to economic development in developing regions. LPDs and other small-or micro-finance institutions collectively hold an important role in alleviating economic upheaval (which continues in the wake of the global economic crisis). ${ }^{15}$ Their social focus allows them to maintain the stability of the economy at a grassroots level. Microfinance can be used as an instrument to reduce poverty since it gives access to financial services for members of society which are excluded from the formal banking sector. ${ }^{16}$

Ending poverty is one of the outcomes (Goal 1) covered in the Sustainable Development Goals (SDGs) promoted by the United Nations. ${ }^{17}$ One of the strategies promoted by the UN to end poverty is to ensure that everyone, including the poor and vulnerable, has equal rights to economic resources. They must have access to basic services, including access to finance (including 'microfinance'). ${ }^{18}$ This is reflected by

14 "Badung Serahkan Hadiah Untuk 12 LPD Berprestasi", December 12, 2014,https:/ /www.badungkab.go.id/index.php/baca-berita/857/Badung-Serahkan-Hadiah-Untuk-12-LPD-Berprestasi.

15 Carol Warren, Loc.cit.

16 Umakanth Varottil, "Microfinance and the Corporate Governance Conundrum," Berkeley Business Law Journal 9, no. 1 (2012): 244.

17 “Sustainable Development Goals," United Nation, accessed May 28, 2018, https://www.un.org/ sustainabledevelopment/sustainable-development-goals/.

18 UN General Assembly, "Transforming Our World: The 2030 Agenda for Sustainable Development", 21 October 2015, A/RES/70/1, available at: http://www.refworld.org/docid/57b6e3e44.html, Goal 1, para. 1.4. 
the promotion of microfinance within the ASEAN socio-cultural community, where it has been held to promote human capital development, economic self-reliance and sustainable livelihoods, especially among the poor. ${ }^{19}$

Australia, Indonesia's immediate neighbour, permits analogous programs to the First Nations Australian Credit Union and First Nations Foundation program which provide Aboriginal and Torres Strait Islander people access to culturally appropriate financial products and services. ${ }^{20}$ Thus, it becomes relevant to address the issues faced by small size or traditional financial institutions (LPD) and their role in the alleviation of poverty.

There are many studies concerning LPDs. Sukandia conducted research on the legal status of LPDs. ${ }^{21}$ This research concludes that the LPD is an essential part of Balinese customary village, and therefore its recognition under Indonesian law is said to be the same as the recognition of the customary village itself.

Sadiartha carried out qualitative research ${ }^{22}$ that conceptualized the LPD as a superior model for traditional financial institutions and acknowledged their role in supporting the economic development of the people of Bali. ${ }^{23}$ This research concludes that LPDs can develop into formidable financial institutions due to their autonomy and that their focus on local issues is related to their reliance on local regulations and awig-awig, rather than national law and policy, as their primary guidance. ${ }^{24}$ It also demonstrates that LPDs are capable of implementing modern banking management principles (i.e. management functions, the ' $5 \mathrm{C}$ ' principles (Character, Capacity, Capital, Collateral, and Condition of the Economy) to anticipate the likelihood of bad loans, ${ }^{25}$ and innovative LPD products in alignment with the local practice of Hindu philosophy, i.e. prosperity under Tri Hita Karana). ${ }^{26}$ A review of this literature indicates that LPDs are capable of operating prudently without compromising their traditional and communal character. Their grassroots nature arguably guides their financial management as well as traditional banks (in ideal circumstances). ${ }^{27}$

19 ASEAN Socio-Cultural Community Blueprint 2025, p. 8, available at: http://asean.org/ storage/2016/01/ASCC-Blueprint-2025.pdf

20 Ingrid Burkett and Genevieve Sheehan, "From the Margins to the Mainstream: The challenges for microfinance in Australia," Fitzroy, Australia: Brotherhood of St Laurence (2009), 39.

21 I Nyoman Sukandia, "Kedudukan Hukum dan Fungsi Lembaga Perkreditan Desa (LPD) sebagai Lembaga Perekonomian Komunitas Dalam Masyarakat Hukum Adat di Bali," (PhD. diss., Universitas Brawijaya, 2012), 7.

22 Anak Agung Ngurah Gede Sadiartha, "Lembaga Perkreditan Desa sebagai Penopang Ke-Ajegan Budaya Ekonomi Masyarakat Bali," Jurnal Kajian Bali 7, no.2 (2017): 7.

23 Ibid, 4-5.

24 Ibid, 15.

25 Ibid, 10.

26 Ibid, 11

27 Ibid, 15. 
A review of the governance practices of LPD seen from the perspective of local cultural values was performed by Ketut Sonya Adnyani. She conducted a qualitative research at LPD Pecatu by doing interviews with 5 informants at corporate level, observations, and documentations. ${ }^{28}$ The study concludes that good governance practices of LPD Pecatu is due to leadership at the corporate level, such as the head of LPD Pecatu, supervisory body, and Chief of the desa adat, who are able to run the governance administration based on cultural values, especially the teachings of Hinduism, the so-called Catur Purusa Artha. ${ }^{29}$

Research concerning small size or local financial institutions is not only conducted in Indonesia. Howell and Wilson conducted a research concerning the problem of financial exclusion in Australia. ${ }^{30}$ The writers underscore the importance of MFIs in providing loans to community organisations, low-income households, and small-scale businesses or entrepreneurs. ${ }^{31}$ Davis conducted a study concerning the microfinance legal framework. This research concluded that MFIs can provide financial services to segments of the population who are ordinarily excluded from the mainstream banking sector in developing countries (provided sound legal frameworks for microfinance are established). ${ }^{32}$ Makuyana conducted research concerning certain aspects of the new microfinance laws in Zimbabwe. ${ }^{33}$ The research concluded that the new microfinance laws in Zimbabwe can be classified as socially progressive legislation because they prioritize the rights of the consumer. ${ }^{34}$ Another example is the study concerning Financial Performance of Microfinance Institutions in Cameroon, conducted by Ofeh and Jeanne. ${ }^{35}$ The research found that MFIs played an important role during the global economic crisis. However, the research suggested that MFIs in Cameroon need to improve their management policies and also reduce operating costs and credit risk management. ${ }^{36}$

28 Ketut Sonya Adnyani, "Praktik Tata Kelola dalam Perspektif Nilai Budaya Lokal pada Lembaga Perkreditan Desa (LPD)" (Thesis, Magister of Accounting, Universitas Gadjah Mada, 2017), xiii

29 Ibid, 82-83.

30 Nicola Howell and Therese Wilson, "Access to Consumer Credit: The Problem of Financial Exclusion in Australia and the Current Regulatory Framework," Macquarie Law Journal 5, no. 7 (2005):134..

31 Ibid, 221.

32 Ian Davis, "Rural Banking: Designing an Effective Legal Framework for Microfinance," Journal of Business, Entrepreneurship and the Law 2, no.2 (2009): 423.

33 Tsanangurai Makuyana, "Some Aspects of the New Microfinance Law in Zimbabwe," Mediterranean Journal of Social Sciences 8, no. 3 (May 2017), 209.

34 Ibid, 216; see further Section 16 (a) (c) of The 2013 Micro Finance Act of Zimbabwe.

35 Moses A. Ofeh and Zangue Ngueku Jeanne, "Financial Performance of Microfinance Institutions in Cameroon: Case of CamCCUL Ltd." International Journal of Economics and Finance 9, no. 4 (2017): 209.

36 Ibid. 


\section{Result and Analysis}

\subsection{Legal status and Institutional Arrangement of LPDs}

\subsubsection{How Indonesian National Law Regulates LPDs?}

The recognition of Balinese customary villages predates the independence of Indonesia. Since the colonial period, customary villages (along with official villages or 'desa dinas') have formed part of a dualistic model of local governance in Bali. ${ }^{37}$ The recognition of customary villages in Indonesia is guaranteed by Article 18B (2) of the Indonesian Constitution, ${ }^{38}$ which stipulates that the State will 'respect and recognise' customary law (or adat) to the extent that it does not contradict with legislation. ${ }^{39}$ Furthermore, Article 28I (3) stipulates that the cultural identity and rights of traditional communities are to be respected, along with their right tocontrol their development. Similar provisions can also be found in Article 6 (2) of Act No. 39 Year 1999 concerning Human Rights.

Traditional communities and their rights are also mentioned in several national statutes, including inter alia Act No. 5 Year 1960 concerning Agraria ('the Agrarian Law'), Act No. 31 Year 2004 concerning Fisheries, and Act No. 6 Year 2014 concerning Village ('Act No. 6/2014'). Unlike the other national laws, Act No. 6/2014 does not only mention or grants recognition but also regulates the rights and obligations, as well as the institutional arrangements, of customary villages.

The recognition of customary villages is also reaffirmed in several court decisions. The Constitutional Court of Indonesia in the Decision No.35/PUU-X/2012 ruled that the customary village is recognised based on Article 18B (2) of the Constitution and thus it is entitled to owned a certain territory, including the forest. ${ }^{40}$ The Court of Appeal of Sumatera Utara is also confirmed the recognition of customary village along with its rights, including property rights ${ }^{41}$.

As an institution owned by Balinese customary village, it could be argued that the existence of LPD itself is implicitly assured by Article 18B (2) of the Indonesian Constitution. ${ }^{42}$ As the LPD is an essential component of the customary village structure, its specific recognition under Indonesian law is said to be the same as the customary village itself. ${ }^{43}$ The status of the LPD is officially recognised in Act No. 1 Year 2013 concerning Micro Finance Institutions - however, as stipulated in Article 39 (3) of

37 Carol Warren, Op.Cit, 170.

38 Undang-Undang Dasar Negara Republik Indonesia Tahun 1945 [The 1945 Constitution of the Republic of Indonesia]; Art.18B (2).

39 Ibid.

40 Decision of the Constitutional Court of Indonesia No. 35/PUU-X/2012, 179.

41 Decision of the Court of Appeal of Sumatera Utara No. 16/PDT/2011/PT.MDN, 5-6.

42 Constitution of the Republic of Indonesia 1945; Article 18B (2).

43 I Nyoman Sukandia, Op.Cit, 7. 
that Act, LPDs are recognised as being governed based on customary law, and thus LPDs are not subject to the rules stipulated in that Act. ${ }^{44}$ In other words, LPDs are not classified as MFIs and are exempted from the MFI regulatory regime.

Government at national level respects the existence of the customary village by giving recognition instead of making regulations and forcing the customary village to comply with it. However, the government at the provincial level went a step further by enacting the LPD Regulations and the Implementing Rules in 2017. These regulations codified common rules on the operation of LPDs in Balinese Customary Law (awig-awig or perarem). LPD Regulations do not only provide common customary rules, but also stipulate several new provisions. These include the requirement for the establishment and capital of LPDs, a monitoring, and protection system, administrative and criminal sanction.

\subsubsection{How Balinese Customary Law Regulates LPDs?}

The rules governing LPDs come from a number of sources, which can be broadly categorized as customary law and State (national) law. Since the beginning of their existence, customary law has played a dominant role in the governance of LPDs. The customary law of Bali is a complex set of normative rules, both written and unwritten. They are strongly influenced by traditional philosophies and principles, the most prominent among these being Tri Hita Karana, which roughly translates as The Three Aspects of Harmony. This concept divides the aspects of Balinese life into harmony with God (parahyangan), harmony with others (pawongan), and harmony with the environment (palemahan), and compels Balinese to balance the three. ${ }^{45}$ This concept has existed long before the proliferation of Corporate Social Responsibility $(\mathrm{CSR})^{46}$ outside of the West. While debate exists around mandatory rules versus voluntary guidelines for CSR by foreign companies operating in Indonesia, ${ }^{47}$

44 See also Ni Made Devi Jayanthi, "Status dan Kedudukan Hukum Lembaga Perkreditan Desa (LPD) terkait Pengikatan Jaminan dengan Berlakunya Undang-Undang Nomor 1 Tahun 2013 Tentang Lembaga Keuangan Mikro" (Thesis, Magister of Notary, Postgraduate Program, Universitas Udayana, 2016), vii.

45 Tjokorda Raka Dherana, Masyarakat Desa dan Awig-Awig dalam Struktur Pemerintahan Bali [The Village People and Awig-Awig in Government Structure Bali], Denpasar, Bali: PT. Upada Literature (1995), 133.

46 Generally, CSR is perceived as the integration of economic consideration and environmental and social imperatives. The economic consideration is related to traditional business focus namely to gain profit. Economic consideration is related to several issues, i.e. corporate governance, anti-corruption, etc. Environmental issues are usually linked with sustainability, as well as some social issues such as human rights, labour, and local community: see Michael Kerr, Richard Janda, and Chip Pitts, Corporate social responsibility: A Legal Analysis (Markham, Ontarion: LexisNexis, 2009), 9.

47 Ibid, 241. The debate concerning mandatory and voluntary CSR is discussed in Decision of the Constitutional Court of Indonesia No. 53/PUU-VI/2008. 104-105. The verdict which decided by majority vote $(6$ out of 9 judges ruled that CSR within the context of Article 74 of Act No. 40 Year 2007 Concerning Corporation is obligatory for every corporation who engage in natural resources business. However, there are 3 judges who gave a joint dissenting opinion. According to their dissenting opinion, CSR is a commitment and not a legal obligation and thus CSR has a voluntary nature. 
LPDs build their core policies around Tri Hita Karana, which is considered by Balinese people to be a holistic source of normative values far more comprehensive than the ethics underpinning CSR.

In Bali, codified customary rules (adat) are known as Awig-awig or Pararem, ${ }^{48}$ and these rule-sets are made both at the Pakraman level or in sub-groups known as Banjar Adat: ${ }^{49}$ residents decide these rules either through a general assembly of eligible voters or with their consent, by an elected ad-hoc committee. ${ }^{50}$ As a result, Awig-awig and Perarem differ from village to village, and no uniform arrangements for LPD governance exist so far as pure adat is concerned.

\subsubsection{Financial Products Offered by LPD}

As other financial institutions, LPDs offers typical financial services such as loans and savings. Before LPD Regulations was created in 2002, LPD carried out those activities based on the customary law (awig-awig or perarem) which made by the customary village. Nowadays, LPDs have a solid legal basis for their performance under Article 7 (1) of the LPD Regulations. This Article limits the valid business operations of LPDs to the following fields:

1. receive/collect funds from members of a customary village in the form of savings and deposits;

2. provide loans to the members of a customary village and to the customary village itself; and

3. provide loans to a member of other customary villages only if there is a co-operation agreement between the customary villages.

Nevertheless, some LPDs develop a wide variety of service to the customer. For instance, LPD Desa Adat Pecatu offers several products, such as Saving Plus (Tabungan Ida Ngaben), ${ }^{51}$ Deposit Plus (Sibermas), ${ }^{52}$ and collateral free-loan (Kredit

48 Wayan P. Windia and Ketut Sudantra, Hukum Adat Bali [Bali Customary Law], Denpasar: Institute for Documentation and Publication Law Faculty Udayana University (2006), 6-7.See for example I Gusti Agung Mas Rwa Jayantiari, "Eksistensi Tanah Adat di Bali dan Problematika Hukum dalam Pengembangan Investasi," Kertha Patrika 39, no. 2 (2017): 117, doi: https://doi.org/10.24843/KP.2017.v39.i02.p03.

49 Wayan P. Windia, Danda Pacamil; Catatan Populer Istilah Hukum Adat Bali /Note of Popular Terms of Balinese Customary Law], Denpasar: Upada Literature (2004), 1-2. Banjar Adat is groups of people who are part of Pakraman having a very strong bond within a certain territorial unit, led by a person or group of persons elected by the council members.

50 Ibid, 3.

51 Almost all members of the Pecatu customary village choose this product in order to fund a traditional ceremony (Ngaben).

52 Sibermas stands for Simpanan Bersama Masyarakat (similar to 'time deposit'). Firstly, the customer and LPD have to agree on the maturity term (the length or period of the deposit). The customers cannot withdraw their funds before the date of maturity. By choosing this product, customer can get higher interest rate. 
Tanpa Agunan or 'KTA'). ${ }^{53}$ Products offered by LPDs have a socio-cultural dimension compared with those offered by other financial institutions such as banks. For instance, the saving plus which does not only serve as an ordinary saving account. In case of demise, the customer who has a saving plus account will get financial support from LPD Pecatu to fund the Ngaben ceremony (Balinese traditional funeral ceremony). ${ }^{54}$

\subsubsection{Customers of LPD}

Since an LPD is owned by a customary village, it has been widely recognised that financial activities can only be exercised within the limit of that village. This basic rule existed in Balinese customary law before LPD Regulations. However, in practice, many LPDs expanded their financial activities by providing loans to outsiders. This practice became a serious issue when the government of Bali enacted LPD Regulations in 2002, in which Article 7 of that regulation stipulates clearly that LPDs are only allowed to provide loans to members of the customary village. Such provision was amended in 2017 after complaints were received from Balinese LPD managers.

The 2017 LPD Regulations provide a breakthrough adjustment under Article 7 (1) c where LPDs are allowed to give a loan to other members of the customary village. However, LPDs who want to lend money to outsiders should make a co-operation agreement which complies with the requirements set forth in Article 6 of the Implementing Rules. Pursuant to that Article, the co-operation agreement must provide for: the terms and conditions for giving loan to a members of other customary villages; right and obligation of each customary village; and dispute settlement provision. This provision gives a more flexible framework for LPDs to expand their activities beyond the remit of the territory of the village community. Lending money to outsiders is an exception of the general rule stipulated under Article 3 of the Regulations. Pursuant that Article, village credit institution carries out its financial activities within the territory of that particular customary village and for the benefit of the member of such customary village. In addition, according to Article 4 (2) of the Regulations, each customary village can only have one LPD. This limitation was created to ensure that each LPD was focusing on the development of that particular customary village instead of conducting fully commercial activities and competing with other LPDs and financial institutions.

\subsection{The Monitoring System of LPD}

The employee's primary obligation is to work, and being absent from work with Managers have dominant control over the assets and daily operation of their LPD.

53 KTA is a short term loan with low interest that only available for members of Pecatu customary village. The maximum amount that can be borrowed is Indonesian Rupiah (IDR) 20 Billion

54 LPD Desa Adat Pecatu, "Produk Unggulan Kami," accessed May 28, 2018, https://lpdpecatu.or.id/1pd_pecatu/. 
Furthermore, management possess a relatively high degree of autonomy in creating policy as LPDs are not subject to the standard national regulations, i.e. the MFI or general banking rules. ${ }^{55}$ Deficiency in the monitoring systems of LPDs may expose tendencies towards misconduct or abuse within LPDs management. For example, in 2011, the Bali Post reported that in Karangasem Regency, about 15 per cent of the region's LPDs had collapsed for reasons of non-performing loans or mismanagement. ${ }^{56}$ In addition, Antara Bali reported in 2013 that 42 LPDs in Tabanan Regency were facing bank ruptcy due to mismanagement, with managers and staff facing a criminal investigation. ${ }^{57}$

In 2014, the Bali Post reported that 30 LPDs in Buleleng Regency had ceased most of their activities, with 15 failing to file reports with the Institute for the Empowerment of LPD ('Lembaga Pemberdayaan LPD' or LPLPD) in 2013. ${ }^{58}$ Even recently, there have been several LPD managers who were prosecuted for mismanagement and/or corruption. For instance, LPD Suwat, Gianyar, was referred by its Pakraman to the Gianyar District Police over alleged embezzlement of funds with total losses estimated as exceeding IDR one billion. ${ }^{59}$ In addition, the Court of Denpasar found that the head of LPD Sinabun (in Buleleng) was guilty of corruption and embezzling client funds. ${ }^{60}$ These continuing cases of widespread maladministration suggest that the monitoring systems of the management of LPDs need to be improved.

\subsubsection{Internal Supervision}

Although there are no uniform customary rules concerning LPDs, some general structural themes are widely observed. Generally speaking, the monitoring of LPDs is conducted at the village level through the peak traditional council of the village, known as Paruman (the meeting). The Bendesa (or 'Chief') of the customary village also acts in a supervisory role and may give directions as to the operation of the LPD if deemed necessary. In cases of negligence or misconduct, the Bendesa will carry out the appropriate sanctions as determined by the Paruman.

55 See subsection 2.1.1.

56 Magister Manajemen Universitas Udayana, "15 Persen LPD di Karangasem Bermasalah," August 24, 2011, https://sites.google.com/a/mmunud.com/dosen/bali/15-persen-lpd-di-karangasembermasalah/pesantanpajudul.

57 The Leader of LPD Belaluan, Kecamatan Sukawati, Gianyar, was found guilty for corruption, see Decision of District Court of Denpasar No. 34/Pid.Sus-TPK/2014/PNDps Tahun 2015;see also "42 LPD Terancam Pailit," accessed 2 December 2015 http://www.antarabali.com/print/36456/42-lpd-terancam-pailit.

58 Bali Post, March 18, 2014, the Board LPD Troubled, accessed 3 December 2015, http://balipost. $\mathrm{com} / \mathrm{read} /$ headline/2014/03/18/7316/pengurus-lpd-bermasalah-dipanggil.html.

59 Bali Post, August 20, 2015, Case Problem LPD Suwat, Party Down LPLPD Had Hand, accessed on 3 December 2015, http://balipost.com/read/kriminal-dan-hukum/2015/08/20/40032/soal-kasus-lpdsuwat-pihak-lpdp-sempat-turun-tangan.html;see Decision of District Court of Denpasar No. 5/Pid.Sus. TPK /2017/PN.Dps:the court ruled that the cashier of LPD Suwat, Gianyar was found guilty for corruption.

60 Decision of District Court of Denpasar No. 36 /Pid.Sus-TPK/2015/PNDpsTahun 2016. 
As of 2002, all LPDs in Bali are, to a limited extent, uniformly regulated at the provincial level. The regulation governing LPD has changed several times. The newest regulation is the 2017 LPD Regulations. Article 10 of the Regulation requires all LPDs to maintain a Management Board and a Supervisory Board composed of the Bendesa and other trustees. The Regulations also require two independent sources of monitoring and supervision: internal and external. Article 1 (11) mandates the formation of an internal supervision committee that reports to the customary village and is composed of members of the community. The internal supervision regulated under the Regulations are similar to the supervision rules that generally recognised in Balinese customary law. In other words, the rules on supervision reflect best practice.

\subsubsection{External Supervision}

Besides the internal supervision, LPD Regulations requires external supervision of LPDs. The obligation to perform external supervision is mandated to LPLPD, an institution created by the provincial authority. ${ }^{61}$ The LPLPD is financially supported by the "empowerment fee". Every LPD should contribute to the empowerment fee by depositing 5 per cent of its net profits. ${ }^{62}$ As well as acting in a guidance and development role, the LPLPD is empowered to carry out certain regulatory and supervisory roles.

The rules on LPD supervision further enhanced in the 2017 Implementing Rules. According to Article 17 of the Regulations and Article 30 of the Implementing Rules, the LPD Board must deliver monthly, quarterly and annual report. These reports will be addressed to the Bendesa via the internal supervisory board. In addition, LPD management Board also has to deliver these reports to LPLPD (external reporting). LPLPD will distribute the reports to the Governor, Regent or Mayor. Before 2017, LPLPD has a powerful instrument to ensure the compliance of LPD with the regulation. Article 32 of the 2013 Implementing Rules set forth that LPLPD has an authority to issue administrative sanctions in order to ensure compliance with regulations, including the provision of official warnings regarding violations; recommendations to dismiss of a member of the Board, or the entire Board, if serious failures persist; and referral of serious misconduct that constitutes criminal conduct to the appropriate authorities. Articles 24, 25 and 26 of the LPD Regulations also impose criminal liability for "deviation from the applicable provisions or negligence" causing "direct or indirect harm to LPD" by a manager or employee of an LPD. Article 26 (as amended in 2012) sets the maximum penalty for this breach as three months imprisonment and a fine of IDR 50 million. These provisions are removed in 2017 and thus LPLPD only can ensure compliance through "soft" means.

The 2017 Regulations and Implementing Rules impose a duplicated monitoring

\footnotetext{
61 LPD Regulations, Art.1(14).
}

62 LPD Regulations, Art. 23 
process on LPDs. Although the LPLPD has the ability to carry out monitoring functions, no division of monitoring functions between the LPLPD and the Pakraman internal watchdog is made clear, and it causes a defect in the implementation of supervisory system of LPD such as permitting serious misconduct to go undetected (in some instances) until the damage is already done. As the reports of the LPLPD are not routinely made available to the public, objective assessment of their performance is hampered.

An issue commonly reported by major stakeholders is that, although the LPLPD collects reports from participating LPDs, little verification or analysis takes place. LPD Pecatu, one of the largest LPDs in Bali province, is a typical example of the rapid development that LPDs and their host communities have experienced. Based on interviews with I Ketut Giriarta, ${ }^{63}$ the Leader of LPD Pecatu, the LPLPD's monitoring functions are not yet properly implemented in Bali. During the time that LPD Pecatu has been subject to the LPLPD's reporting requirements, the LPLPD never made attempts to verify or cross-check the content of the reports of LPD Pecatu. In addition, LPLPD never offered the coaching or empowerment services it claims to. The failure of the LPLPD to provide reports to the LPDs that support it make it difficult for the managers of LPDs to assess the LPLPD's performance and overall benefit to the LPD.

The performance of the LPLPD itself is not subject to detailed monitoring, and its performance standards are not clearly set by regulation - a factor that may contribute to the ineffectiveness of the LPLPD as a supervisory body. In particular, the LPDs that do co-operate with the LPLPD in good faith receive little feedback or assistance from the LPLPD, despite this being the agency's primary stated mission. Prior to 2017, the LPLPD is empowered to impose significant penalties on non-complying LPDs, however, it appears to be hesitant to do so in practice. As a result, certain LPDs continue to operate with blatant disregard for State law. The 2017 Regulations do not provide for the imposition of sanctions.

There are - at least - two constraints that contribute to the LPLPD's less optimum performance. Firstly, the nature of LPD as a part of the customary village make it difficult to be regulated by the Regulations. The customary village has obtained recognition based on the Indonesia constitution as an autonomous entity and thus it is difficult to apply outside rule (i.e. LPD Regulations) within the customary village. Second, the duties of the LPLPD are outweighing its capacity. The LPLPD need to have sufficient resource, experts, and facilities in order to perform its function properly. Moreover, the number of LPDs that must be supervised are more than a thousand. In fact, the LPLPD is facing lack of experts and resources. This limitation means that the LPLPD cannot achieve its main goal, namely to oversee and empower all LPDs in Bali.

63 I Ketut Giriarta, Chief of LPD Desa Adat Pecatu, interview by Luh Putu Yeyen Karista Putri and Eric Gordon Withnall, December 4, 2015. 
Due to lack of supervision, some LPDs in Bali are facing mismanagement issue. This issue can ruin the reputation of an LPD and also trigger public distrust. Trust is essential for any financial institution. If the monitoring mechanism of LPD is not improved, the customer will switch to other financial institutions such as banks. Banks have a better monitoring mechanism because they are supervised by the Central bank of Indonesia and Otoritas Jasa Keuangan (The Authority of Financial Institution or 'OJK'). If this situation continues, LPDs will be abandoned by their customers and the existence of LPDs as a community-based financial institution will be threatened. The Leader of LPD Desa Adat Pecatu is aware of the importance of an audit to a financial institution. Therefore, LPD Desa Pecatu hires a public accountant to audit its liquidity annually. This undertaking is conducted to ensure the good management of the LPD and the results of the audit are used for future planning. ${ }^{64}$

\subsection{Protection Mechanism of LPD}

\subsubsection{Financial Risk}

Finance services are exposed to certain risks. These risks include: credit risk, market risk, operational risk, ${ }^{65}$ liquidity risk, reputational risk, strategic risk, legal risk, ${ }^{66}$ and systemic risk. ${ }^{67}$ This paper discusses only the risks of credit, operational and liquidity, those believed to be the most relevant to LPDs. Some LPDs in Bali are dealing with non-performing loans where the customer cannot fulfil their repayment obligations. In addition, some LPDs are also exposed to a risk of loss resulting from inadequate internal processes or failed management systems. ${ }^{68}$ There is also a serious concern with regard to liquidity risk that may disable a bank from carrying out day-to-day cash transactions. ${ }^{69}$

\subsubsection{Protection Mechanism under Customary Law}

As LPDs have begun to operate on the same level as commercial banking institutions, they are beginning to face the same kinds of financial risk faced by commercial banks. Considering the number of assets owned by some LPDs, it can be fairly said that responsible risk management practices are required to safeguard the rights of customers, as well as the rights of the beneficiaries of LPDs.

64 Michael Power, “The Invention of Operational Risk", Review of International Political Economy 12, No. 4 (October 2005): 580.

65 Ibid.

66 I Wayan Suartana and I Ketut Jati, "Risk Based Internal Audit Based on Culture: Case Study at LPD Desa Adat Pecatu in Bali," Journal of Economics and Sustainable Development 8, no. 18 (2017): 199.

67 Ian Davis, Op.Cit., 399.

68 See Lembaga Penjamin Simpanan, Op. Cit.

69 See Kontan, Op. Cit. 
Balinese Customary Law enforces no uniform protection for LPD customers. Traditionally, the personal transactions of LPDs are conducted with a reliance on the principle of lascarya (trust and sincerity). Within the customary village with strong community interest and involvement in the management of LPDs, traditional sanctions as decided by the Paruman ${ }^{70}$ have previously been effective. Any dispute will be settled amicably and if there are customers who fail to pay the loan, the Paruman usually gives them a second chance. However, if they cannot fulfil the obligation or if they commit severe violations, they may be punished. Historically, a villager's overwhelming dependence on a harmonious relationship with the village may have been sufficient to ensure the compliance in the loan agreement. However, the rapid economic development of Bali means that individual residents now have more financial mobility than ever. Therefore, social sanctions are no longer sufficient in all cases to ensure compliance in the loan agreements.

\subsubsection{Protection Mechanism under LPD Regulations}

As substantiated in subsection 2.3.1, LPDs are exposed (mainly) by three types of risks, namely: operational risk (related to mismanagement), credit risk (borne out of non-performing loans) and liquidity risk (related with cash reserve and a customer's money). In order to protect LPDs from operational risk, the LPD Regulations stipulate a double system of supervision (internal and external) as substantiated in subsection 2.2.1 and 2.2.2.

The management of credit risk is regulated in the Implementing Rules. As stipulated in Article 10 of the Implementing Rules, an LPD is only allowed to give loan up to 20 per cent of the total capital. In addition, pursuant to Article 12, LPDs are obliged to classify loan provided to customers into four categories based on their collectability. They are: performing loan (kredit lancar), hampered (kredit kurang lancar), delinquent (kredit diragukan), and non-performing loan (macet). ${ }^{71}$ These classifications are used as a basis to determine the strategy of credit management. Pursuant to Article 14 of the Implementing Rules, LPDs have three options in restructuring the credit. First, the time limit or deadline for the payment can be extended (known as 'rescheduling'). Second, the terms/conditions that stipulated in the credit contract can be amended or modified (known as 'reconditioning'). Lastly, LPD can combine those two options. If this strategy is failed, then LPD can take the last resort, namely sell the security through an auction. ${ }^{72}$ Such credit management is commonly used by banks and other financial institutions.

Article 8 of the Implementing Rules stipulates that LPDs have to maintain their reserve with the minimum threshold of 12 per cent of the total capital. This provision is important to tackle liquidity risk. In addition, Articles 21 and 22 provide

\footnotetext{
70 See Subsection 2.2.1.

71 Implementing Rules, Art. 13 (1).

72 Implementing Rules, Art. 17.
} 
rules on liquidity management in which LPDs should maintain their reserve (cash supply) minimum 20 per cent of the total capital. LPD Regulations also provides specific rules on a protection scheme as a risk management strategy. Pursuant to Article 22 (1) of the Regulations, the LPLPD has the responsibility to perform a protection scheme. The LPD Protection Scheme is a fund specifically established to preserve LPDs and prevent insolvency. ${ }^{73}$ The scheme is only available for the members who comply with the obligations set forth in the LPD Regulations, including pay the empowerment fee. This obligation is stipulated in Article 23 (1) of the Regulations. According to Article 23 (1), the net profit of LPDs at the end of a financial year shall be allocated as follows:
a. Capital reserves $60 \%$ (sixty percent);
b. Rural Development funds 20\% (twenty percent);
c. Production Services 10\% (ten percent);
d. Empowerment Fund 5\% (five percent) or not exceed IDR 300 billion; and
e. Social Fund 5\% (five percent).

The empowerment fund of 5 per cent must be paid to the LPLPD as its main source of funding in order to enable its guidance and empowerment functions. However, in practice, a number of LPDs refuse to pay the fee - so far without retribution - and as a result, the LPLPD's effective budget become smaller than originally intended. According to the Head of LPD Desa Adat Pecatu, many smaller LPDs informally report that, without any meaningful benefit to participating in the LPLPD, spending 5 per cent of the LPD's profits is unacceptable to the interests of the community. Many larger and well-funded LPDs believe the fee is unnecessary.

As a specialized financial institution, LPDs have special protection and guarantees as stipulated in Chapter XII of the Regulations. Article 22 (1) mandates the existence of the Protection Scheme whereby LPDs can borrow funds in order to avoid insolvency; Article 22 (2) establishes a "Scheme Protection Fund" funded jointly by LPDs that can be used to guarantee customer deposits.

It is difficult to implement the consumer protection and guarantee mechanisms stipulated in the Regulations. The main constraint is the difficulty in collecting the empowerment fund from all LPDs in Bali. With only a few who pay the development fund, the Scheme Protection Fund excludes many LPDs from its protective capabilities. This further contributes to the issue of LPDs in Bali refusing to contribute to the LPLPD, causing other LPDs to view the development fund to be futile. This further inhibits assurance mechanisms and protections for both LPDs and customers. The provincial government tried to improve LPLPD's performance and reputation by requiring a stricter reporting system under Article 69 of the 2017 Implementing Rules. However, there are no consequences or sanction that will be imposed to LPDs

73 Official explanatory note of Art. 22 (1) of the LPD Regulations. 
that fail to pay the empowerment fee. Consequently, the new reporting requirement cannot automatically ensure the compliance of LPDs to pay empowerment fee.

\subsubsection{Protection Mechanism in LPD Pecatu}

Regardless of the relative lack of protection systems provided for in the Regulations, some LPDs in Bali are experiencing rapid development because customers trust those institutions on the basis of their previous record. As an example, LPD Pecatu (which holds assets more than IDR 300 Billion) regularly reviews its own customary rules, and in April 2015, the customary village of Pecatu enacted an improved Perarem to regulate its LPD. ${ }^{74}$ Pursuant to Article 35 (1) of the Perarem, a customer who wants to apply for a loan must now fulfil the requirements stipulated in the Credit System and Procedures of LPD Pecatu. The loan application will be assessed by a special committee, chaired by the Chief of the customary village of Pecatu. Article 35 (2) states that customers seeking loans will be bound by a letter of credit agreement. The credit agreements are in the form of a standard contract. The contents of the credit agreement can be adjusted if the parties so desire. ${ }^{75}$ These basic guidelines ensure that the operation of LPDs like Pecatu is undertaken with relative prudence.

The actual credit agreement, in the absence of special regulation, falls under the Indonesian Civil Law as stipulated in the Civil Code and other general legislation. Article 1338 (1) of the Civil Code stipulates the basic principle of pacta sunt servanda. According to this principle, every (valid) contract is binding upon the parties to it and must be performed by them in good faith. Accordingly, the parties to the credit agreement (i.e. LPD and its customer) should comply with the provisions stipulated in the contract. Moreover, all of a debtor's assets, including "the movable and immovable assets," are considered security for a debtor's personal agreements, as stipulated in Articles 1131 and 1132 of the Indonesian Civil Code. If the customer wishes to provide their land as security, the LPD as the lender is also protected by Act No. 4 of 1996 on Mortgage Regulation. ${ }^{76}$ LPD Pecatu also maintains the credit management standards stipulated in the Implementing Rules, including the credit classification requirement.

In order to ensure legal protection, LPD Desa Adat Pecatu builds a co-operation with a Legal Consultant. ${ }^{77}$ The legal consultant gives legal advice and also helps with

74 Perarem Pangele Desa Adat Pecatu tentang Lembaga Perkreditan Desa (LPD) Desa Adat Pecatu [Customary Rules of the Customary Village of Pecatu regarding the Village Credit Institution of the Customary Village of Pecatu], 25 April 2015.

75 Ahmadi Miru, 2007, the Contract Law and Contract Design, PT. RajaGrafindo Persada, Jakarta, p. 39. The standard contract is a contract clause that have been set or designed by one party.

76 Undang-Undang Republik Indonesia Nomor 4 Tahun 1996 tentang Hak Tanggungan [Law 4/ 1996 regarding Mortgage Regulation].

77 I Nyoman Krisnadinata Wijaya, Legal Officer of LPD Desa Adat Pecatu, interview by Luh Putu Yeyen Karista Putri, June 2, 2018. 
drafting the credit contract and other legal papers. In addition, the legal consultant also assists with auction ${ }^{78}$ or litigation ${ }^{79}$ arrangements. However, LPD Desa Adat Pecatu has never been summoned by the court or become a party to a legal dispute - this is clearly not characteristic of all LPDs.

LPD Desa Adat Pecatu also takes initiative to empower its employees and implements its internal supervision strategies through seminars and other undertakings. This LPD has invited experts, professors, and industry professionals to educate and develop its employees. In addition, LPDs also seek advice from expertise (such as former bank directors) and therefore LPD Pecatu manages its balance sheet carefully.

LPD Desa Adat Pecatu also arranges its own protection system by offering insurance to its customers. This effort is taken to minimize the risk of the unexpected (force majeure). According to the information from the head of credit administrative section of LPD Pecatu, the majority of customers agree to sign up for insurance to cover their loan. LPD have claimed insurance several times due to the demise of its customers. ${ }^{80}$ Without the insurance, it would be difficult for an LPD to collect loans caused by demise or other unexpected incidents (risks). Therefore, LPD Pecatu has a new policy, requiring customers who have a loan of more than IDR 20 million to insure their loan. ${ }^{81}$ In order to provide more protection to its customer, LPD Pecatu builds co-operation with several insurances companies.

The protection system initiated by LPD Desa Adat Pecatu cannot be compared with the protection system of banks. Unlike banks, LPDs in Bali do not have an effective protection scheme, thus LPD customers are exposed to greater risk. The customers of Indonesian banks are protected by Lembaga Penjamin Simpanan (Indonesia Deposit Insurance Corporation). Customers will likely find more protection and choose bank instead of an LPD. More over, there are a lot of MFIs which provides financial services to lower and middle-class society. ${ }^{82}$ If protection systems are not improved, LPDs cannot compete with other financial institutions, particularly banks. The issue of protection system may jeopardize the existence of LPD as a traditional financial institution in the long term.

78 Ibid. This is the last resort that will be undertaken by LPD after other means (i.e. rescheduling, reconditioning and restructuration) are failed. LPD Pecatu will sell the collateral or mortgage through an auction in order to repay the customer's loan. Before going to auction, LPD Pecatu will give (the first, second and third) notifications to the customer.

79 Ibid. LPD Pecatu hired a legal consultant to give advice and present before the court. LPD Pecatu prefers pacific dispute settlement but it also anticipates the possibility of being involved in a civil or criminal case.

80 Ni Wayan Kariasih, Head of Credit Administration of LPD Desa Adat Pecatu, interview by Luh Putu Yeyen Karista Putri, May 25, 2018.

81 Ibid.

82 I Gde Kajeng Baskara, "Lembaga Keuangan Micro di Indonesia," Buletin Studi Ekonomi 18, No.2, (2013): 123 


\section{Conclusion}

It is very important to strike a balance between preserving the unique (traditional) character of LPD and creating a standard management to protect the customer. The existence of LPD is inseparable from Balinese customary villages which have been recognised based on the Indonesian Constitution and several national laws. The traditional framework is working well for some LPDs and they succeed to support the economic development of the customary village and its members. Meanwhile, other LPDs face an issue of mismanagement due to lack of standardisation of monitoring and protection system. The 2017 LPD Regulations and the Implementing Rules provide rules on monitoring and protection mechanism of LPDs. Such rules correspond to the monitoring and protection system that applied in modern financial institutions. The government enacting such rules to set standard management system of LPDs and protect the customer. Hence, it is inevitable for LPDs to adopt modern financial institution management.

The monitoring system provided in the Regulation consists of internal and external supervision. The internal supervision is led by the Chief of the customary village while the external supervision is conducted by the LPLPD. The internal supervision can generate a significant impact through the imposition of sanctions to the LPDs' management who fail to exercise its obligation. Some LPDs, including LPD Pecatu, complement this monitoring system by using service of a public accountant to audit their management board. Meanwhile, the LPLPD cannot perform its function optimally due to limitation of resource and inability to impose sanctions. In addition, some LPDs stop delivering the periodical report to the LPLPD due to insignificant feedback they receive. An effort to improve the LPLPD's performance has been taken by imposing a stricter reporting requirement. It will be better if the LPD Regulations and Implementing Rules also provide authority for the LPLPD to impose sanctions in order to ensure regulatory compliance of LPDs.

LPLPD is also mandated to perform the protection scheme. However, the scheme cannot be implemented properly due to the difficulty in collecting the empowerment fund. The monitoring and protection system establish based on the Regulations and the Implementing Rules is more desirable for LPD instead of direct intervention from the OJK. The benchmark set for other modern financial institutions might be applied to LPDs. However, the implementation of the monitoring and protection system should be improved in a way that respects the autonomy of customary villages. In addition, every individual LPD is encouraged to take initiative to improve the protection system otherwise, customers may choose other financial institutions.

\section{Acknowledgement}

Authors would like to express our gratitude to head and staff of Faculty of Law Udayana University and Charles Darwin University School of Law, as well as head and staff of LPD Pecatu. The information, views, and arguments set out in this article are those of the authors in the context of academic research and do not necessarily reflect the opinion of their job affiliation. 


\section{BIBLIOGRAPHY}

\section{Book}

Dherana, Tjokorda Raka. Masyarakat Desa dan Awig-Awig dalam Struktur Pemerintahan Bali [the Village People and Awig-Awig in Government Structure Bali]. Bali: PT. Upada Literature, 1995.

Kerr, Michael, Richard Janda, and Chip Pitts. Corporate Social Responsibility: A legal analysis. Markham, Ontario: LexisNexis, 2009.

Miru, Ahmadi. Hukum Kontrak dan Perancangan Kontrak [the Contract Law and Contract Design]. Jakarta: PT. Raja Grafindo Persada, 2007.

Warren, Carol. "Adat in Balinese Discourse and Practice." In The Revival of Tradition in Indonesian Politics: The Deployment of Adat from Colonialism to Indigenism, edited by Jamie S. Davidson and David Henley, 170-202. Oxford: Routledge, 2007.

Windia, Wayan P. and Ketut Sudantra. Hukum Adat Bali [Bali Customary Law]. Denpasar: Institute for Documentation and Publication Law Faculty Udayana University, 2006.

Windia, Wayan P. Danda Pacamil; Catatan Populer Istilah Hukum Adat Bali [Note of Popular Terms of Balinese Customary Law]. Denpasar: Upada Literature, 2004.

\section{Journal Article}

Baskara, I Gde Kajeng. "Lembaga Keuangan Micro di Indonesia." Buletin Studi Ekonomi 18, no.2 (2013): 114-125.

Davis, Ian. "Rural Banking: Designing an Effective Legal Framework for Microfinance." The Journal of Business, Entrepreneurship \& the Law 2, no. 2 (2009): 394-423.

Howell, Nicola and Therese Wilson. "Access to Consumer Credit: The Problem of Financial Exclusion in Australia and the Current Regulatory Framework." Macquarie Law Journal 5, no. 7 (2005):127-148.

Jayantiari, I Gusti Agung Mas Rwa. "Eksistensi Tanah Adat di Bali dan Problematika Hukum dalam Pengembangan Investasi." Kertha Patrika 39, no. 2 (2017): 108199, doi: https://doi.org/10.24843/KP.2017.v39.i02.p03. 
Ndun, Hanna Christine, Sarah Suttor, and I Gusti Agung Ayu Dike Widhiyaastuti. "Does Customary Law Discriminate Balinese Women's Inheritance Rights?" Udayana Journal of Law and Culture 2, no. 1 (2018): 97-114, https://doi. org/10.24843/UJLC.2017.v02.i01.p05.

Ofeh, Moses A., and Zangue Nguekeu Jeanne. "Financial Performances of Microfinance Institutions in Cameroon: Case of CamCCUL Ltd." International Journal of Economics and Finance 9, no. 4 (2017): 207-224.

Power, Michael. "The Invention of Operational Risk". Review of International Political Economy 12, no. 4 (2005): 577-599. https://doi. org/10.1080/09692290500240271

Prijandhini Devi Salain, M. "Perlindungan Hukum Terhadap Kebudayaan Bali Sebagai Sumber Daya Ekonomi Pariwisata.” Kertha Patrika 39, no. 1 (2017): 1-15, doi: https:/ / doi.org/10.24843/KP.2017.v39.i01.p01.

Sadiartha, Anak Agung Ngurah Gede. "Lembaga Perkreditan Desa sebagai Penopang Ke-Ajegan Budaya Ekonomi Masyarakat Bali." Jurnal Kajian Bali 7, no. 2 (2017): 1-18.

Suartana, I Wayan and I Ketut Jati. "Risk-Based Internal Audit Based on Culture: Case Study at LPD Desa Adat Pecatu in Bali" Journal of Economics and Sustainable Development 8, no. 18 (2017): 190-200.

Susila, Gede Putu Agus Jana. "Pengukuran Kinerja Lembaga Perkreditan Desa (LPD) Kecamatan Susut Dengan Analisis Balanced Scorecard." Jurnal Ilmu Sosial dan Humaniora 5, no.2 (2016): 810-816. http://dx.doi.org/ 10.23887/ jish-undiksha.v5i2.8564

Varottil, Umakanth. "Microfinance and the Corporate Governance Conundrum." Berkeley Business Law Journal 9, no 1 (2013): 242-292.

\section{Thesis or Dissertation}

Adnyani, Ketut Sonya. "Praktik Tata Kelola dalam Perspektif Nilai Budaya Lokal pada Lembaga Perkreditan Desa (LPD)." Thesis, Magister of Accounting, Universitas Gadjah Mada, 2017.

Jayanthi, Ni Made Devi. "Status dan Kedudukan Hukum Lembaga Perkreditan Desa (LPD) terkait Pengikatan Jaminan dengan Berlakunya Undang-Undang Nomor 1 Tahun 2013 Tentang Lembaga Keuangan Mikro.” Thesis, Magister of Notary, Universitas Udayana, 2016. 
Sukandia, I Nyoman. "Kedudukan Hukum dan Fungsi Lembaga Perkreditan Desa (LPD) sebagai Lembaga Perekonomian Komunitas dalam Masyarakat Hukum Adat di Bali." PhD diss., Faculty of Law Universitas Brawijaya, 2012.

\section{Legal Documents}

Undang-Undang Dasar Negara Republik Indonesia Tahun 1945 [The 1945 Constitution of the Republic of Indonesia].

Undang-Undang Republik Indonesia Nomor 4 Tahun 1996 tentang Hak Tanggungan [Act No. 4/1996 regarding Mortgage Regulation].

Undang-Undang Republik Indonesia Nomor 39 Tahun 1999 tentang Hak Asasi Manusia [Act No. 39/1999 concerning Human Rights].

Undang-Undang Republik Indonesia Nomor 1 Tahun 2013 tentang Lembaga Keuangan Mikro [Act No. 1/2013 concerning Micro Finance Institutions].

Undang-Undang Republik Indonesia Nomor 6 Tahun 2014 tentang Desa [Act No. 6/2014 concerning Village].

The 2013 Microfinance Act of Zimbabwe. Availableathttp://www.veritaszim.net/ sites/veritas_d/files / Microfinance\%20Act\%20\%5BChapter\%2024-29\%5D.pdf.

Peraturan Daerah Provinsi Bali Nomor 3 Tahun 2017 tentang Lembaga Perkreditan Desa [Local Regulation of Bali Province No. 3/2017 concerning Village Credit Institution].

Peraturan Gubernur Bali Nomor 44 Tahun 2017 tentang Peraturan Pelaksanaan Peraturan Daerah Provinsi Bali Nomor 3 Tahun 2017 tentang Lembaga Perkreditan Desa [Governor Regulation of Bali No. 44/2017 concerning Implementation Rules of Local Regulation of Bali Province No. 3/2017 concerning Village Credit Institution].

Joint Decree by Minister of Finance, Minister for Domestic Affairs, Minister of Co-operative and Small and Middle size-Enterprises, and Governor of Central Bank of Indonesia No: 351.1/KMK.010/2009; No: 900-639A Tahun 2009; No: 01/SKB/M.KUKM/IX/2009; No: 11/43A/KEP.GBI/2009 concerning Strategy to Develop Micro Finance Institution.

Perarem Pangele Desa Adat Pecatu tentang Lembaga Perkreditan Desa (LPD) Desa Adat Pecatu [Customary Rules of the Customary Village of Pecatu regarding the Village Credit Institution of the Customary Village of Pecatu]. 


\section{Other Documents}

ASEAN Socio-Cultural Community Blueprint 2025. http://asean.org/ storage/2016/01/ASCC-Blueprint-2025.pdf.

Ingrid Burkett and Genevieve Sheehan, "From the Margins to the Mainstream: The Challenges for Microfinance in Australia", Fitzroy, Australia: Brotherhood of St Laurence (2009).

UN General Assembly. "Transforming Our World: The 2030 Agenda for Sustainable Development", 21 October 2015, A/RES/70/1.Available at http://www.refworld.org/docid/57b6e3e44.html.

\section{Interview}

Giriarta, I Ketut, Chief of LPD Desa Adat Pecatu. Interview by Luh Putu Yeyen Karista Putri and Eric Gordon Withnall, December 4, 2015.

Kariasih, Ni Wayan, Head of Credit Administration of LPD Desa Adat Pecatu. Interview by Luh Putu Yeyen Karista Putri, May 25, 2018.

Wijaya, I Nyoman Krisnadinata, Legal Officer of LPD Desa Adat Pecatu. Interview by Luh Putu Yeyen Karista Putri, June 2, 2018.

\section{Case Law}

Putusan Mahkamah Konstitusi Republik Indonesia [Decision of the Constitutional Court of Indonesia] No. 53/PUU-VI/2008.

Putusan Mahkamah Konstitusi Republik Indonesia [Decision of the Constitutional Court of Indonesia] No. 35/PUU-X/2012.

Putusan Pengadilan Negeri Denpasar [Decision of the District Court of Denpasar] No. 34/Pid.Sus-TPK/2014/PNDpsTahun 2015.

Putusan Pengadilan Negeri Denpasar [Decision of District Court of Denpasar]No. 36 /Pid.Sus-TPK/2015/PNDps Tahun 2016.

Putusan Pengadilan Negeri Denpasar [Decision of the District Court of Denpasar] No. 5/Pid.Sus.TPK /2017/PN.Dps Tahun 2017.

Putusan Pengadilan Tinggi Sumatera Utara [Decision of the Court of Appeal of Sumatera Utara] No. 16/PDT/2011/PT.MDN. 


\section{Website Content}

AA Seri Kusniarti, "Dewan LPD Seperti Bank Indonesia." Tribun Bali. Last modified October 23, 2015, http:/ / bali.tribunnews.com/2015/10/23/dewan-lpd-sepertibank-Indonesia.

Antara Bali. Maret 31, 2013. “42 LPD Terancam Pailit.” Accessed 2 December 2015. https:/ / bali.antaranews.com/berita/36456/42-lpd-terancam-pailit

Bali Post. August 20, 2015."Case Problem LPD Suwat, Party Down LPLPD Had Hand. "Accessed 3 December 2015. http://balipost.com/read/kriminaldanhukum/2015/08/20/40032/soal-kasus-lpd-suwat-pihak-1pdp-sempatturun-tangan.html.

Bali Post. March 18, 2014."The Board LPD Troubled.” Accessed 3 December 2015. http:/ / balipost.com/read/headline/2014/03/18/7316/pengurus-lpd-bermasalah-dipanggil.html.

Indonesia Satu. Co. "OJK Ingatkan LPD Bali yang Gagal Bayar Uang Nasabah." Last modified August 24, 2016. http://indonesiasatu.co/detail/ojk-ingatkanlpd-bali-yang-gagal-bayar-uang-nasabah.

Kabarnusa.com. "Kekayaan LPD di Bali capai 15,5 Triliun." Last modified April 29, 2017. https://www.kabarnusa.com/2017/04/kekayaan-lpd-di-bali-capairp155-triliun.html.

Kontan.co.id. "BI Bali Desak Pembentukan Pengawasan LPD.” Last modified October 18, 2016. http:// regional.kontan.co.id/news/bi-bali-desak-pembentukan-pengawasan-1pd.

Lembaga Penjamin Simpanan. "Establishment, Status, and Designated Positions of IDIC.” Accessed May 1, 2018. http://www.lps.go.id/en/web/guest/bentuk-status.

LPD Desa Adat Pecatu. "Produk Unggulan Kami.” Accessed May 28, 2018. https:// lpdpecatu.or.id/1pd_pecatu/.

Magister Manajemen Universitas Udayana. "15 Persen LPD di Karangasem Bermasalah." Last modified August 24, 2011 . https://sites.google.com/a/ mmunud.com/dosen/bali/15-persen-lpd-di-karangasem-bermasalah/pesantanpajudul.

Pemerintah Kabupaten Badung. "Badung Serahkan Hadiah Untuk 12 LPD Berprestasi", Last modified Desember 12, 2014, https://www.badungkab.go.id/index.php/ baca-berita/ 857 / Badung-Serahkan-Hadiah-Untuk-12-LPD-Berprestasi.

United Nations."Sustainable Development Goals.” Accessed May 28, 2018. https:// www.un.org/sustainabledevelopment/sustainable-development-goals/. 